\title{
PENGEMBANGAN INSTRUMEN PENILAIAN SIKAP DISIPLIN MENGGUNAKAN SKALA LIKERT DALAM PEMBELAJARAN TEMATIK KELAS IV SD
}

\author{
Fransiska Ayuka Putri Pradana \& Mawardi \\ Universitas Kristen Satya Wacana \\ fransiskaayukaa@gmail.com,mawardi@staff.uksw.edu
}

\begin{abstract}
The current problem faced regarding environmental condition is the low public awareness to protect and preserve the environment. It is because of the lack of society's discipline in protecting the environment, so it needs something to track their discipline attitude to take care of the environment. Here I focus on the students' discipline attitude as an object of my research. Thus, this research aimed to produce a discipline attitude assessment instrument using Likert scale and to find out the validity and feasibility of the discipline attitude assessment instrument using Likert scale for thematic learning in fourth grade students of elementary school about environmental discipline. This research implemented research and development (R\&D) design. The instrument validity was analyzed by an attitude assessment expert with a score of $85.7 \%$, by an instructional design expert with a score of $91.8 \%$, and by a linguist with a score of $91.3 \%$. Based on the validations of those three aspects, the score was categorized as 'very high'. Therefore, the developed discipline attitude assessment instrument using Likert scale is very feasible to use.
\end{abstract}

Keywords: Development, Discipline Attitude Assessment Instrument, Likert Scale

\begin{abstract}
Abstrak: Permasalahan yang sering dihadapi tentang kondisi lingkungan adalah rendahnya tingkat kesadaran masyarakat untuk menjaga dan melestarikan lingkungan. Hal tersebut terjadi karena kurangnya kedisiplinan dalam menjaga lingkungan sehingga diperlukan pelacakan sikap disiplin siswa melalui sebuah penelitian. Dengan demikian tujuan penelitian ini adalah untuk menghasilkan produk berupa instrumen penilaian sikap disiplin dengan menggunakan skala Likert dalam pembelajaran tematik untuk siswa kelas IV SD serta untuk mengetahui tingkat validitas dan kelayakan produk instrumen penilaian sikap disiplin dengan menggunakan skala Likert dalam pembelajaran tematik untuk siswa kelas IV SD tema 9 subtema 2 tentang disiplin lingkungan. Penelitian iniamenggunakan jenis penelitian dan pengembangan $(R \& D)$. Produk instrumen diuji tingkat validitasnya oleh ahli penilaian sikap dengan skor $85,7 \%$. ahli desain pembelajaran dengan skor $91,8 \%$, dan ahli bahasa dengan skor $91,3 \%$. Berdasarkan hasil validasi dari ketiga aspek tersebut, makaaskor masuk dalam kategori sangat tinggi dan produk instrumen penilaian sikap disiplin dengan menggunakan skala Likert sangat layak untuk digunakan.
\end{abstract}

Kata Kunci : Pengembangan, Instrumen Penilaian Sikap Disiplin, Skala Likert

Fondatia : Jurnal Pendidikan Dasar

Volume 5, Nomor 1, Maret 2021; 13-29

https://ejournal.stitpn.ac.id/index.php/fondatia 


\section{PENDAHULUAN}

Sesuai dengan Permendikbud No. 24 Tahun 2016 tentang Kompetensi Inti dan Kompetensi Dasar menyebutkan bahwa kurikulum 2013 memiliki kompetensi inti berupa tingkat kemampuan yang harus dimiliki peserta didik untuk mencapai standar kompetensi lulusan pada setiap tingkatan kelas (Kemendikbud, 2016). ${ }^{1}$ Kompetensi inti tersebut terdiri dari kompetensi inti untuk mengukur aspek sikap spiritual, sikap sosial, pengetahuan, dan keterampilan. Ketiga faktor tersebut harus dapat dikembangkan secara luas dalam pembelajaran agar tujuan pembelajaran dapat tercapai dengan baik.

Menurut (Prastowo, 2015) tujuan pembelajaran adalah kompetensi yang harus dikuasai oleh siswa yang sifatnya operasional dan harus dicapai oleh siswa. Untuk mencapai tujuan pembelajaran, terdapat komponen penting yang ada dalam penyusunan rancangan pembelajaran yaitu materi pembelajaran. ${ }^{2}$ Dalam proses pelaksanaan pembelajaran, guru harus menggunakan strategi yang tepat dalam menyampaikan materi pembelajaran. (Djamarah, 2013) menjelaskan bahwa strategi adalah kegiatan umum antara guru dan siswa dalam proses kegiatan belajar mengajar untuk mencapai tujuan pembelajaran yang telah ditetapkan. Dalam melaksanakan strategi pembelajaran, diperlukan juga sebuah metode pembelajaran seperti tanya jawab, diskusi, ceramah, dan penugasan. Penugasan berfungsi untuk mendapatkan informasi tentang kemampuan siswa yang nantinya akan dijadikan sebuah penilaian.

Penilaian sikap adalah kegiatan yang dapat dilakukan oleh seorang pendidik untuk mendapatkan informasi mengenai perilaku peserta didik. Penilaian sikap dapat dilakukan pada saat proses pembelajaran maupun di luar pembelajaran. Sesuai dengan Kompetensi Inti dalam Kurikulum 2013, terdapat 2 aspek sikap yang dapat dinilai yaitu sikap spiritual dan sikap sosial. Penilaian sikap sosial sesuai (KI-2) meliputi sikap jujur, disiplin, tanggung jawab, dan santun. Salah satu sikap yang dimiliki siswa untuk menunjukkan perilaku tertib dan patuh terhadap peraturan adalah sikap disiplin.

\footnotetext{
${ }^{1}$ Kemendikbud. (2016). Permendikbud Nomor 24 Tabun 2016 tentang Kompetensi Inti dan Kompetensi Dasar. Kementerian Pendidikan dan Kebudayaan RI. Hal.3.

2 Prastowo, A. (2015). Menyusun Rencana Pelaksanaan Pembelajaran (RPP) tematik Terpadu. Penerbit Kencana. Hal.73.
} 
Sekarang ini banyak sekali permasalahan yang timbul di Indonesia, salah satunya bencana alam yaitu banjir. Seperti yang terjadi saat ini, banjir melanda Ibukota Indonesia. Peristiwa ini sudah menjadi hal biasa bagi warga Ibukota. Banyak faktor yang menyebabkan terjadinya banjir di wilayah Ibukota, diantaranya karena turunnya curah hujan yang tinggi, area serapan air yang kurang, tata guna lahan yang berubah, tidak memadainya saluran - saluran air, serta kurangnya kepedulian masyarakat terhadap lingkungan (Kompas, 17 September 2020). Faktor tersebut terjadi karena manusia tidak disiplin untuk menjaga lingkungan sekitar. Sering dijumpai juga bahwa siswa tidak disiplin ketika berada di lingkungan sekolah dan rumah. Berdasarkan pengamatan yang dilakukan di Sekolah Dasar yang berada di Kota Salatiga, masih terdapat beberapa siswa yang perlu diingatkan agar mereka membuang sampah di tempat sampah. Sikap disiplin untuk menjaga dan merawat lingkungan perlu ditanamkan kepada siswa.

Disiplin merupakan kegiatan yang dilakukan oleh setiap siswa untuk melakukan sesuatu secara teratur dan tertib serta penuh tanggung jawab sesuai dengan peraturan yang berlaku (Efendi, 2020) ${ }^{3}$. Oleh karena itu dalam menilai sikap disiplin yang dilakukan oleh siswa, guru perlu menggunakan indikator - indikator penilaian sikap disiplin. Sikap disiplin dapat dinilai dengan mengamati kehadiran peserta didik, mengikuti peraturan yanga da di sekolah, dll. Namun sebaiknya guru perlu mengembangkan indikator - indikator penilaian sikap disiplin sesuai dengan keaadaan yang ada di sekolah atau sesuai dengan materi yang dipelajari oleh siswa. Berdasarkan hasil wawancara yang dilakukan dengan guru di 3 SD yang berada di Kota Salatiga didapatkan hasil bahwa belum terdapat instrumen penilaian untuk menilai aspek sikap disiplin pada kelas IV terutama sikap dsiplin terhadap lingkungan. Untuk menilai sikap disiplin masih menggunakan teknik observasi dan ada yang menggunakan rubrik penilaian namun belum diujikan validitas atau kelayakannya.

Tujuan penelitian ini adalah untuk menghasilkan produk berupa instrumen penilaian sikap disiplin dengan menggunakan skala Likert dalam pembelajaran tematik untuk siswa kelas IV SD tema 9 Kayanya Negeriku subtema 2 Pemanfaatan Kekayaan Alam di Indonesia serta untuk mengetahui tingkat validitas dan kelayakan

${ }^{3}$ Efendi, R. (2020). Manajemen Kelas di Sekolah Dasar. CV Penerbit Qiara Media. Hal.38. 
instrumen yang dihasilkan. Produk instrumen penilaian sikap disiplin dapat digunakan untuk mempermudah guru dalam menilai sikap disiplin siswa kelas IV SD.

Proses pembelajaran harus dilaksanakan secara interaktif, menyenangkan, aktif sesuai dengan minat, bakat dan kemampuan peserta didik. Penilaian merupakan hal yang tidak bisa dipisahkan dari proses pembelajaran dan proses penilaian dapat menentukan kualitas dari sebuah kegiatan pembelajaran (Sani, 2016). Penilaian adalah upaya sistematik yang dilakukan melalui pengumpulan data atau informasi yang valid dan reliabel, dan selanjutnya data atau informasi tersebut diolah sebagai upaya melakukan pertimbangan untuk pengambilan kebijakan suatu program pendidikan. ${ }^{4}$ Penilaian digunakan mengukur seluruh aspek kompetensi peserta didik yaitu aspek sikap, pengetahuan, dan keterampilan. Jadi melalui penilaian ini, semua aspek kompetensi siswa dapat diketahui tingkat perkembangannya. Menilai aspek afektif atau sikap peserta merupakan hal yang penting untuk dilakukan oleh guru agar mengetahui perilaku peserta didik pada saat pembelajaran maupun di luar pembelajaran. Sikap berasal dari perasaan suka atau tidak suka yang dimiliki oleh seseorang yang saling berkaitan dengan kecenderungan individu untuk merespon suatu objek (Kunandar, 2014). ${ }^{5}$ Sikap dapat dilihat sebagai suatu ekspresi dari nilai atau pandangan hidup seseorang. Sikap seseorang dapat dibentuk sehingga terjadi tindakan seperti dengan yang diharapkan.

Dalam menyusun instrumen penilaian, langkah yang harus diperhatikan adalah menentukan skala yang digunakan untuk mengukur sikap. Skala yang dapat digunakan untuk mengukur instrumen penilaian sikap adalah Skala Gutman, Skala Likert, dan Skala Thurstone (Wardani, 2012). Dalam penelitian ini, peneliti menggunakan Skala Likert yang dikembangkan oleh Rensis Likert. (Wardani, 2012) mengatakan bahwa Skala Likert digunakan untuk meneliti moral seseorang atau kelompok. Kompetensi yang akan diukur dijabarkan menjadi beberapa indikator yang digunakan untuk menyusun sebuah instrumen yang berupa pertanyaan maupun pernyataan. Jawaban instrumen skala Likert dikembangkan menjadi 4 (empat) kategori dari sangat positif sampai sangat negatif dengan kata-kata yaitu : 1) sangat

${ }^{4}$ Sani, R. (2016). Penilaian Autentik. PT Bumi Aksara.

${ }^{5}$ Kunandar. (2014). Penilaian Autentike (Penilaian Hasil Belajar Peserta Didik Berdasarkan Kurikulum 2013). Raja Grafindo Persada. 
setuju (SS), 2) setuju (S), 3) tidak setuju (TS), dan 4) sangat tidak setuju (STS). ${ }^{6}$ (Mawardi, 2019) menyebutkan langkah-langkah yang digunakan untuk menyusun skala Likert antara lain: 1) menyusun pernyataan obyek sikap; 2) melaksanakan uji coba instrument; 3) menentukan skor untuk masing-masing pernyataan; 4) melakukan analisis item untuk mengetahui kesahihan instrumen.

Penelitian tentang pengembangan instrumen sikap disiplin dilakukan oleh (Wicaksono et al., 2016) dengan judul "Pengembangan Penilaian Sikap dengan Teknik Observasi, Self Assesment, dan Peer Assesment pada Pembelajaran Tematik Kelas V SDN Arjowinangun 02 Malang". Tujuan dari penelitian ini adalah untuk menghasilkan produk berupa instrumen penilaian sikap sosial yang dapat digunakan guru dan siswa untuk menilai diri sendiri dan menilai orang lain. ${ }^{8}$ Penelitian ini menggunakan penelitian pengembangan dengan model ADDIE. Dari hasil penelitian didapatkan hasil bahwa hasil validasi memperoleh persentase sebesar $80 \%$.

Penelitian relevan lainnya adalah penelitian yang dilakukan oleh (Pratiwi \& Fasha, 2015) dengan judul "Pengembangan Instrumen Penilaian HOTS Berbasis Kurikulum 2013 terhadap Sikap Disiplin”. Pengembangan instrumen penilaian sikap ini menggunakan R\&D model 4-D Thiagarajan. ${ }^{9}$ Penilaian yang menggunakan 12 indikator ini memperoleh nilai rata-rata validitas skor sikap disiplin 90\%, dengan hasil skor tersebut instrumen penilaian ini dikatakan efektif dan berhasil sehingga baik digunakan untuk menilai sikap disiplin siswa.

Penelitian relevan lainnya oleh (Kartinah, 2018) dengan judul "Pengembangan Instrumen Pengukuran Sikap Disiplin untuk Siswa Sekolah Menengah Pertama". Penelitian ini bertujuan untuk mengembangkan instrumen disiplin siswa dan mengukur kedisiplinan siswa. $^{10}$ Produk yang dikembangkan berupa 30 butir

${ }^{6}$ Wardani, N. (2012). Asesmen Pembelajaran SD. Widya Sari Press. Hal.208.

7 Mawardi, M. (2019). Rambu-rambu Penyusunan Skala Sikap Model Likert untuk Mengukur Sikap Siswa. Scholaria: Jurnal Pendidikan Dan Kebudayaan, 9(3), Hal.296.

${ }^{8}$ Wicaksono, T. P., Muhardjito, \& Harsiati, T. (2016). Pengembangan Penilaian Sikap dengan Teknik Observasi, Self Assessment, dan Peer Assessment pada Pembelajaran Tematik Kelas V SDN Arjowinangun 02 Malang. Jurnal Pendidikan: Teori, Penelitian, Dan Pengembangan, 1(1), Hal.45.

${ }^{9}$ Pratiwi, U., \& Fasha, E. F. (2015). Pengembangan Instrumen Penilaian Hots Berbasis Kurikulum 2013 Terhadap Sikap Disiplin. Jurnal Penelitian Dan Pembelajaran IP A, 1(1), Hal.123.

10 Kartinah, K. (2018). Pengembangan Instrumen Pengukuran Disiplin untuk Siswa Sekolah Menengah Pertama. Wiyata Dharma: Jurnal Penelitian Dan Evaluasi Pendidikan, 6(2), Hal.102. 
pernyataan. Dari uji validitas didapatkan hasil 81\% Dari hasil tersebut maka produk instrumen penilaian sikap disiplin valid dan layak untuk digunakan.

\section{METODE PENELITIAN}

Dalam penelitian ini, peneliti menggunakan jenis penelitian dan pengembangan atau Research and Development (R\&D). Menurut (Sukmadinata, 2017) penelitian dan pengembangan merupakan suatu cara atau proses yang digunakan untuk mengembangkan produk baru atau menyempurnakan produk yang sudah ada sebelumnya dan dapat dipertanggungjawabkan. ${ }^{11}$ Penelitian dan pengembangan berfungsi untuk memvalidasi dan mengembangkan produk (Sugiyono, 2016). ${ }^{12}$

Produk yang akan dikembangkan oleh peneliti yaitu instrumen penilaian sikap disiplin berupa angket dengan menggunakan skala Likert dalam pembelajaran tematik Kelas IV Tema 9 Kayanya Negeriku Subtema 2 Pemanfaatan Keyakaan Alam di Indonesia. Teknik pengumpulan data menggunakan teknik nontes dengan jenis observasi, wawancara, dan angket menggunakan skala Likert yang dilakukan di SD Kota Salatiga.

Langkah - langkah yang digunakan untuk mengembangkan produk instrumen penilaian menggunakan model penelitian dan pengembangan yang dikembangkan oleh (Sukmadinata, 2017) yang mencakup tiga tahap yaitu: 1) Studi Pendahuluan; 2) Pengembangan Produk; dan 3) Pengujian Produk. Prosedur penelitian disajikan dalam gambar 1 . berikut: ${ }^{13}$

${ }^{11}$ Sukmadinata. (2017). Metode Penelitian Pendidikan. PT Remaja Rosdakarya.

12 Sugiyono. (2016). Metode Penelitian \& Pengembangan Research and Development. Penerbit Alfabeta Cv. Hal.297.

${ }^{13}$ Sukmadinata. (2017). Metode Penelitian Pendidikan. PT Remaja Rosdakarya. 


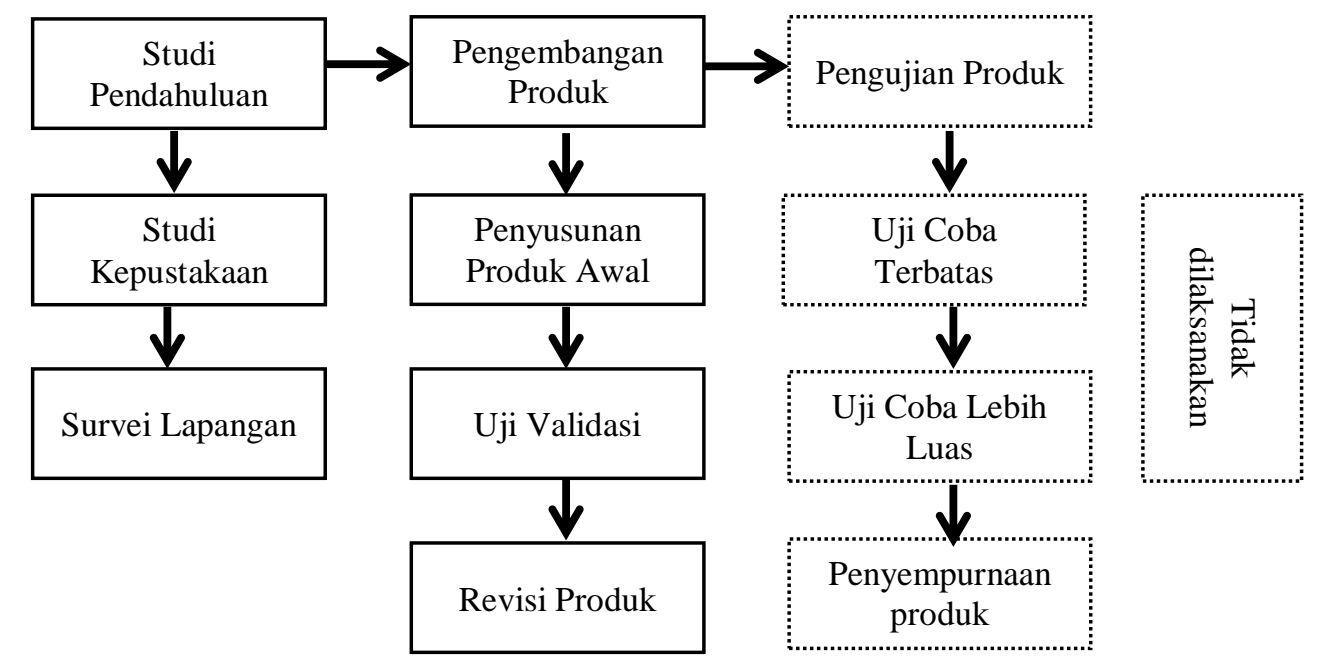

Gambar 1 Prosedur Penelitian Pengembangan

\section{Studi Pendahuluan}

Dalam studi pendahuluan terdapat 2 langkah yaitu studi pustaka dan survei lapangan. Studi pustaka digunakan untuk mempelajari konsep yang akan digunakan untuk membuat produk instrumen penilaian sikap disiplin yang akan dikembangkan. Studi pustaka dilakukan dengan menggunakan jurnal yang relevan, buku-buku, dan sumber relevan lainnya tentang penilaian sikap disiplin. Survei lapangan digunakan untuk mendapatkan data berupa permasalahan dan solusi yang dapat digunakan untuk mengatasi permasalahan dalam pembelajaran. Berdasarkan hasil survei lapangan didapatkan hasil bahwa tidak terdapat instrumen penilaian yang digunakan untuk menilai sikap disiplin siswa kelas IV SD dalam pembelajaran tematik.

\section{Pengembangan Produk}

Pengembangan Produk terdiri atas penyusunan produk awal dan uji validasi produk. Pada tahap penyusunan produk awal topik penelitian yang akan diteliti disesuaikan dengan model pengembangan yang akan dipilih. Model pengembangan yang sesuai dengan pengembangan instrumen penilaian sikap disiplin adalah model pengembangan ADDIE yang dikembangkan Reiser dan Mollenda. Adapun tahapan pengembangan ADDIE yaitu 1) Analysis; 2) Design;

3) Development, 4) Implementation; dan 5) Evaluation dengan penjelasan sebagai berikut:

a. Analysis 
Pada tahap analisis ini dilakukan dengan dua kegiatan yaitu analisis kinerja dan analisis kebutuhan siswa. Dalam analisis kinerja, peneliti mengumpulkan informasi melalui observasi dan wawancara dengan guru di SD Kota Salatiga. Peneliti juga melakukan analisis kebutuhan siswa. Berdasarkan hasil analisis kebutuhan yang diperlukan untuk mengukur sikap disiplin siswa, peneliti perlu menganalisis kurikulum yang digunakan oleh sekolah. Kemudian mengkaji silabus, KI, dan KD kelas IV SD untuk mengembangkan instrumen penilaian sikap disiplin.

b. Design

Tahap perencanaan digunakan untuk menyiapkan rancangan produk penilaian sikap disiplin yang akan dikembangkan. Langkah-langkah dalam merancang penyusunan produk pengembangan instrumen sikap disiplin adalah sebagai berikut : (1) Mengkaji silabus kelas 4 semester 2; (2) menentukan tema dan subtema; (3) menentukan KD yang sesuai dengan sikap yang diukur; (4) menyusun indikator instrumen; (5) menyusun desain pembelajaran dalam RPP; (6) menyusun kisi-kisi instrumen sikap disiplin yang disesuaikan dengan skala Likert.

c. Development

Dalam tahap ini peneliti mengembangkan butir-butir pernyataan dengan menggunakan skala Likert ke dalam angket sesuai dengan indikator yang akan dikembangkan. Butir-butir pernyataan kemudian divalidasi oleh ahli, yaitu ahli penilaian sikap, ahli desain pembalajaran, dan ahli bahasa oleh dosen PGSD FKIP UKSW Masukan-masukan dan saran yang diberikan oleh para ahli dapat digunakan untuk memperbaiki butir-butir pernyataan dalam instrumen penilaian tersebut.

d. Implementation

Produk yang telah divalidasi oleh ahli dan diperbaki kemudian diujicobakan secara terbatas kepada siswa kelas IV SD. Produk diujicobakan melalui pembelajaran sesuai dengan desain pembelajaran.

e. Evaluation

Tahap evaluasi ini dilakukan dengan melakukan perbaikan atau revisi produk yang telah diujicobakan. Produk berupa instrumen penilaian sikap 
disiplin yang telah divalidasi oleh para ahli kemudian diperbaiki dan diujicobakan kembali pada uji coba terbatas dan lebih luas. Hasil analisis dari pengujian tersebut digunakan sebagai acuan untuk memperbaiki produk agar produk tersebut layak untuk digunakan.

\section{Pengujian Produk}

Produk instrumen penilaian sikap disiplin dalam bentuk angket yang telah divalidasi oleh penilaian sikap, ahli desain pembelajaran, dan ahli bahasa kemudian akan diperbaiki atau direvisi berdasarkan masukan-masukan atau saran yang diberikan oleh ahli. Butir - butir pernyataan yang sudah valid kemudian diujicobakan kepada responden yaitu siswa kelas IV SD di Kota Salatiga

Teknik pengumpulan data menggunakan teknik nontes dengan jenis observasi, wawancara, dan angket menggunakan skala Likert yang sudah divalidasi oleh ahli dan diujikan ke SD Kota Salatiga. Teknik analisis data hasil validasi menggunakan teknik deskriptif dan persentase untuk mengetahui tingkat validitas produk yang dibuat. Persentase yang didapatkan dikategorikan dalam tabel 1. berikut :

Tabel 1. Rentang Indeks Validitas

\begin{tabular}{lcc}
\hline No. & Interval & Kategori \\
\hline 1. & $81-100 \%$ & Sangat tinggi \\
2. & $61-81 \%$ & Tinggi \\
3. & $41-60 \%$ & Cukup \\
4. & $21-40 \%$ & Rendah \\
5. & $0-20 \%$ & Sangat rendah
\end{tabular}

Menurut (Mawardi, 2014) hasil uji validasi dikatakan layak untuk diujicobakan apabila presentase minimal adalah $\geq 61 .{ }^{14}$

14 Mawardi. (2014). Model Desain Pembelajaran Konsep Dasar PKn Berbasis Belajar Mandiri menggunakan Moodle. Widya Sari Press. 


\section{HASIL DAN PEMBAHASAN}

Hasil penelitian berdasarkan observasi dan wawancara terhadap guru kelas IV di Kota Salatiga yaitu SD Kristen 03 Eben Haezer, SD Kanisius Gendongan dan SD Kanisius Cungkup didapatkan hasil bahwa masih belum ada instrumen yang digunakan untuk menilai sikap disiplin siswa kelas 4 terutama sikap disiplin lingkungan dalam pembelajaran tematik Kelas IV Tema 9 Kayanya Negeriku Subtema 2 Pemanfaatan Kekayaan Alam di Indonesia. Dalam menilai sikap disiplin, guru hanya menilai melalui observasi dan ada yang menggunakan instrumen sikap disiplin secara umum. Penelitian ini dilakukan karena berdasarkan hasil observasi masih ditemukan siswa yang perlu untuk diingatkan agar membuang sampah pada tempatnya. Oleh karena itu sikap disiplin terhadap lingkungan perlu ditanamkan kepada siswa. Berdasarkan permasalahan tersebut, peneliti menganalisis kebutuhan yang dibutuhkan oleh sekolah dan siswa yaitu instrumen penilaian sikap disiplin terhadap lingkungan dengan menggunakan skala Likert dalam pembelajaran tematik kelas IV SD Tema 9 Kayanya Negeriku Subtema 2 Pemanfaatan Kekayaan Alam di Indonesia dengan muatan pembelajaran PPKn dan Bahasa Indonesia. Materi pembelajaran yaitu mengenai hak dan kewajiban terhadap pemanfaatan sumber energi dan sumber daya alam. Penyusunan produk menggunakan model pengembangan ADDIE yang terdiri atas 1) Analysis; 2) Design; 3) Development; 4) Implementation; dan 5) Evaluation.

Analysis (Tahap Analisis). Pada tahap analisis ini dilakukan dengan dua kegiatan yaitu analisis kinerja dan analisis kebutuhan siswa. Dalam analisis kinerja, peneliti mengumpulkan informasi melalui observasi dan wawancara dengan guru di SD Kota Salatiga. Hasil observasi dan wawancara menyatakan bahwa belum terdapat instrumen penilaian untuk mengukur sikap sosial terutama sikap disiplin terhadap lingkungan dalam pembelajaran tematik kelas IV SD. Peneliti juga melakukan analisis kebutuhan siswa untuk mengukur sikap disiplin siswa. Langkah pertama yaitu menganalisis kurikulum yang digunakan oleh sekolah, mengkaji silabus, KI, dan KD kelas IV SD untuk mengembangkan instrumen penilaian sikap disiplin. Penilaian sikap disiplin menggunakan Kompetensi Dasar muatan pembelajaran PPKn KD 2.2 Menunjukkan sikap disiplin dalam memenuhi kewajiban dan hak sebagai warga 
masyarakat sebagai wujud cinta tanah air. Dari hasil analisis inilah peneliti mengembangkan instrumen penilaian sikap disiplin terhadap lingkungan dalam pembelajaran tematik untuk peserta didik kelas IV Tema 9 "Kayanya Negeriku" Subtema 2 "Pemanfaatan Kekayaan Alam di Indonesia".

Design (Tahap Perancangan). Pada tahap perancangan ini peneliti menyiapkan rancangan produk yang akan dikembangkan untuk menyusun instrumen penilaian sikap disiplin dengan menggunakan skala Likert yang selanjutnya akan dilakukan validasi oleh ahli penilaian sikap, ahli desain pembelajaran, dan ahli bahasa. Rancangan yang disusun oleh peneliti sebagai kebutuhan produk yaitu:

1. Silabus. Silabus yang dikembangkan berdasarkan KI dan KD kelas IV semester 2 Tema 9 Kayanya Negeriku Subtema 2 Pemanfaatan Kekayaan Alam di Indonesia.

2. Rencana Pelaksanaan Pembelajaran (RPP). Desain pembelajaran dirancang dalam bentuk RPP dengan materi pembelajaran tentang hak dan kewajiban terhadap pemanfaatan sumber daya alam.

3. Kisi-kisi instrumen penilaian sikap disiplin dengan indikator objek sikap disiplin lingkungan menggunakan skala Likert dalam pembelajaran tematik kelas IV SD.

Berikut merupakan kisi-kisi instrumen penilaian sikap disiplin lingkungan.

Tabel 2. Kisi-kisi Instrumen Penilaian Sikap Disiplin Lingkungan

\begin{tabular}{lccccc}
\hline \multicolumn{1}{c}{$\begin{array}{c}\text { Komponen } \\
\text { Indikator Objek } \\
\quad \text { Sikap }\end{array}$} & Kognisi & Afeksi & Konasi & Jumlah & $(\%)$ \\
\cline { 2 - 4 } $\begin{array}{l}\text { Hakikat disiplin } \\
\text { lingkungan }\end{array}$ & 4 & 0 & 0 & 4 & $13,3 \%$ \\
$\begin{array}{l}\text { Tujuan disiplin } \\
\text { lingkungan }\end{array}$ & 2 & 2 & 1 & 5 & $16,6 \%$ \\
$\begin{array}{l}\text { Pelestarian } \\
\text { lingkungan alam }\end{array}$ & 1 & 2 & 2 & 5 & $16,6 \%$ \\
$\begin{array}{l}\text { Pemanfaatan } \\
\text { sumber energy }\end{array}$ & 1 & 2 & 3 & 6 & $20 \%$ \\
$\begin{array}{l}\text { Pelestarian hewan } \\
\text { Pelestarian }\end{array}$ & 1 & 2 & 2 & 5 & $16,6 \%$ \\
tumbuhan & 1 & 2 & 2 & 5 & $16,6 \%$ \\
\hline \multicolumn{1}{c}{ Total } & 10 & 10 & 10 & 30 & $100 \%$ \\
\hline
\end{tabular}


Development (Tahap Pengembangan). Pada tahap ini peneliti mengembangkan produk berupa butir-butir pernyataan sejumlah 30 butir sesuai dengan 6 komponen indikator yang telah dirancang di tahap perancangan. Dalam menyusun butir-butir pernyataan harus disesuaikan dengan komponen sikap yaitu komponen kognisi, afeksi, dan konasi. Komponen kognisi menyangkut ide atau keyakinan. Komponen afeksi berhubungan dengan kehidupan emosional, sedangkan komponen konasi menyangkut kecenderungan seseorang untuk berperilaku (Mawardi, 2019). ${ }^{15}$ Butirbutir pernyataan disusun sesuai dengan pernyataan positif dan negatif yang seimbang agar siswa benar-benar membaca pernyataan dengan seksama. Instrumen penilaian disusun menggunakan skala Likert dengan empat pilihan jawaban yaitu SS (sangat setuju), S (setuju), TS (tidak setuju), STS (sangat tidak setuju). Produk yang telah dikembangkan kemudian diujikan validitasnya oleh para ahli yaitu ahli penilaian sikap, ahli desain pembelajaran, dan ahli bahasa.

Hasil validasi ahli penilaian sikap oleh dosen ahli penilaian sikap memperoleh skor $85,7 \%$ dan tergolong dalam interval $81-100 \%$ sehingga termasuk dalam kategori sangat tinggi.

Tabel 3. Hasil Validasi Aspek Penilaian Sikap

\begin{tabular}{lcccc}
\hline \multicolumn{1}{c}{ Aspek } & $\begin{array}{c}\text { Skor } \\
\text { Ideal }\end{array}$ & $\begin{array}{c}\text { Skor } \\
\text { Aktual }\end{array}$ & $\begin{array}{c}\text { Persentase } \\
\text { Kelayakan }\end{array}$ & Kategori \\
\hline $\begin{array}{l}\text { Kriteria Penilaian } \\
\text { Sikap }\end{array}$ & 56 & 48 & $85,7 \%$ & Sangat Tinggi \\
\hline Rata-rata hasil validasi aspek penilaian sikap & $85,7 \%$ & Sangat tinggi \\
\hline
\end{tabular}

Tabel 3. menunjukkan bahwa hasil validasi ahli penilaian sikap terhadap produk pengembangan instrumen penilaian sikap disiplin untuk siswa kelas IV mendapatkan skor persentase kelayakan sebesar 85,7\% dan sangat layak digunakan. Aspek penilaian sikap yang divalidasi yaitu kriteria penilaian sikap menurut Allen Edward dalam (Mawardi, 2019) yang meliputi : (1) pernyataan tidak mengandung unsur masa lalu; (2) pernyataan tidak berupa fakta; (3) pernyataan tidak mengandung makna ganda; (4) pernyataan relevan dengan objek yang diukur; (5) tidak ada pernyataan yang memiliki

${ }^{15}$ Mawardi, M. (2019). Hal.293. 
kemungkinan besar disetujui semua orang; (6) pemilihan pernyatan mancakup tentang skala afektif yang diinginkan; (7) pernyataan ditulis dalam bahasa sederhana, jelas, dan langsung; (8) pernyataan ditulis menggunakan kalimat yang jelas, ringkas, dan tidak lebih dari 20 kata; (9) setiap pernyataan berisi 1 ide atau gagasan; (10) pernyataan tidak mengandung unsur universal; (11) pernyataan tidak mengandung kata "hanya", "sekedar", dan "semata-mata"; (12) pernyataan disusun menggunakan kalimat sederhana, tidak majemuk atau kompleks; (13) pernyataan tidak menggunakan kalimat yang sulit dimengerti oleh pembaca; (14) pernyataan tidak menggunakan kata negatif ganda. ${ }^{16}$

Hasil validasi ahli desain pembelajaran oleh dosen ahli pembelajaran memperoleh skor 94\% dan tergolong dalam interval $81-100 \%$ sehingga termasuk dalam kategori sangat tinggi. Rata-rata hasil validasi aspek desain pembelajaran dijabarkan dalam tabel 4. berikut:

Tabel 4. Hasil Validasi Aspek Desain Pembelajaran

\begin{tabular}{lcccc}
\hline \multicolumn{1}{c}{ Aspek } & $\begin{array}{c}\text { Skor } \\
\text { Ideal }\end{array}$ & $\begin{array}{c}\text { Skor } \\
\text { Aktual }\end{array}$ & $\begin{array}{c}\text { Persentase } \\
\text { Kelayakan }\end{array}$ & Kategori \\
& 52 & 50 & $96,1 \%$ & Sangat Tinggi \\
Komponen & 16 & 14 & $87,5 \%$ & Sangat Tinggi \\
Prinsip & & & $91,8 \%$ & Sangat Tinggi \\
\hline Rata-rata hasil validasi aspek desain pembelajaran & & & \\
\hline
\end{tabular}

Dari hasil rata-rata validasi aspek desain pembelajaran, produk instrumen yang dikembangkan sangat layak digunakan dengan persentase rata-rata sebesar 94\%. Aspek yang digunakan terdiri dari komponen pembelajaran dan prinsip pembelajaran sesuai dengan Permendikbud No. 22 Tahun 2016 (Kemendikbud, 2016). Komponen pembelajaran memiliki persentase kelayakan sebesar 96,1\% dengan indikator sebagai berikut: (1) identitas sekolah; (2) identitas mata pelajaran, tema, dan subtema; (3) kelas/semester; (4) materi pokok; (5) alokasi waktu; (6) tujuan pembelajaran berdasarkan kompetensi dasar; (7) kompetensi dasar dan indikator pencapaian kompetensi; (8) materi pembelajaran sesuai dengan indikator pencapaian kompetensi;

16 Mawardi, M. (2019). Rambu-rambu Penyusunan Skala Sikap Model Likert untuk Mengukur Sikap Siswa. Scholaria: Jurnal Pendidikan Dan Kebudayaan, 9(3), 297 
(9) metode/model pembelajaran; (10) media pembelajaran; (11) sumber belajar; (12) langkah-langkah pembelajaran; (13) penilaian hasil belajar. Sedangkan prinsip pembelajaran mendapatkan hasil persentase kelayakan sebesar 87,5\% dengan kategori sangat tinggi dengan indikator meliputi (1) keaktifan siswa dalam proses pembelajaran; (2) keterlibatan siswa dalam proses pembelajaran; (3) pengembangan budaya membaca, menulis, dan berekspresi dalam berbagai bentuk tulisan; (4) keterpaduan muatan pembelajaran. ${ }^{17}$

Hasil validasi ahli penilaian sikap oleh dosen ahli penilaian sikap memperoleh skor $85,7 \%$ dan tergolong dalam interval $81-100 \%$ sehingga termasuk dalam kategori sangat tinggi.

Tabel 5. Hasil Validasi Aspek Bahasa

\begin{tabular}{lcccc}
\hline \multicolumn{1}{c}{ Aspek } & $\begin{array}{c}\text { Skor } \\
\text { Ideal }\end{array}$ & $\begin{array}{c}\text { Skor } \\
\text { Aktual }\end{array}$ & $\begin{array}{c}\text { Persentase } \\
\text { Kelayakan }\end{array}$ & Kategori \\
\hline Lugas & 12 & 11 & $85,7 \%$ & Sangat Tinggi \\
Komunikatif & 4 & 4 & $100 \%$ & Sangat Tinggi \\
Dialogis dan interaktif & 8 & 6 & $75 \%$ & Tinggi \\
Kesesuaian dengan & 8 & 7 & $87,5 \%$ & Sangat Tinggi \\
perkembangan siswa & 8 & 8 & $100 \%$ & Sangat Tinggi \\
$\begin{array}{l}\text { Kesesuaian dengan } \\
\text { kaidah Bahasa Indonesia }\end{array}$ & 8 & 8 & $100 \%$ & Sangat Tinggi \\
Penggunaan istilah, & & & & Sangat Tinggi \\
simbol, dan ikon. & & & & \\
\hline Rata-rata hasil validasi aspek Bahasa & & & & \\
\hline
\end{tabular}

Berdasarkan hasil dari tabel 5. hasil validasi dalam aspek bahasa memiliki ratarata persentase kelayakan sebesar 91,3\% dengan kategori sangat tinggi dan sangat layak untuk digunakan. Aspek yang digunakan dalam validasi bahasa terdiri dari 6 aspek menurut (Purnanto \& Mustadi, 2018) yaitu: (1) lugas; (2) komunikatif; (3) dialogis dan interaktif; (4) kesesuaian dengan perkembangan siswa; (5) kesesuaian dengan kaidah Bahasa Indonesia; dan (6) penggunaan istilah, simbol, dan ikon. Aspek

${ }^{17}$ Kemendikbud. (2016). Permendikbud Nomor 22 Tahun 2016 tentang Standar Proses Pendidikan Dasar dan Menengah. Kementerian Pendidikan dan Kebudayaan RI. Hal.6. 
lugas mendapatkan skor kelayakan sebesar 85,7\% dengan indikator (a) ketepatan struktur kalimat; (b) keefektifan kalimat; dan (c) kebakuan istilah. ${ }^{18}$ Aspek komunikatif memiliki persentase kelayakan sebesar 100\% dengan indikator yaitu pemahaman terhadap pesan atau informasi. Aspek dialogis dan interaktif mendapatkan persentase kelayakan sebesar 75\% dengan kategori tinggi dan memiliki 2 butir indikator yaitu (a) bahasa yang digunakan dapat memotivasi siswa; dan (b) bahasa yang digunakan dapat mendorong siswa untuk berpikir kritis. Aspek selanjutnya yaitu sesuai dengan perkembangan siswa memiliki persentase kelayakan sebesar 87,5\% dengan kategori sangat tinggi dan memiliki 2 butir indikator yaitu: (a) kesesuaian dengan tingkat perkembangan intelektual siswa; dan (b) kesesuaian dengan tingkat perkembangan emosional siswa. Aspek berikutnya yaitu kesesuaian dengan Kaidah Bahasa Indonesia memiliki skor persentase kelayakan sebesar 100\% dengan kategori sangat tinggi dan memiliki 2 butir indikator yaitu: (a) ketepatan tata bahasa yang digunakan; dan (b) ketepatan ejaan mengacu pada pedoman EYD. Aspek terakhir yaitu penggunaan istilah, simbol, dan ikon dengan persentase kelayakan sebesar 100\% dengan kategori sangat tinggi dan terdiri atas 2 indikator yaitu: (a) konsistensi penggunaan istilah; dan (b) konsistensi penggunaan simbol atau ikon.

Implementation (Tahap Implementasi). Produk pengembangan berupa angket instrumen penilaian sikap disiplin yang sudah divalidasi oleh para ahli kemudian diujicobakan secara terbatas dan luas kepada siswa kelas IV SD dalam pembelajaran. Namun, peneliti tidak dapat melaksanakan tahap implementasi karena terjadinya pandemi COVID-19 yang mengakibatkan terjadinya pembelajaran secara daring dan tidak masuk ke sekolah sehingga peneliti tidak dapat mengujicobakan produk kepada siswa.

Evaluation (Tahap Evaluasi). Tahap evaluasi ini dilakukan untuk memperbaiki produk-produk yang telah disusun dari setiap tahapannya. Hasil validasi oleh para ahli kemudian dianalisis untuk mendapatkan hasil kelayakan produk instrumen yang dikembangkan. Dari hasil uji validasi ahli penilaian sikap, ahli desain pembelajaran, dan ahli bahasa didapatkan skor kelayakan penilaian sikap sebesar 85,7\%, skor kelayakan desain pembelajaran sebesar 91,8\% dan skor kelayakan bahasa sebesar

18 Purnanto, A. W., \& Mustadi, A. (2018). Analisis Kelayakan Bahasa Dalam Buku Teks Tema 1 Kelas I Sekolah Dasar Kurikulum 2013. Profesi Pendidikan Dasar, 3(2), Hal.103. 
91,3\%. Skor tersebut tergolong dalam kategori sangat tinggi dan sangat layak untuk digunakan.

\section{KESIMPULAN}

Penelitian ini menghasilkan produk berupa pengembangan instrumen penilaian sikap disiplin menggunakan skala Likert dalam pembelajaran tematik kelas IV SD. Produk ini sangat layak digunakan untuk menilai sikap disiplin siswa kelas IV Tema 9 Kayanya Negeriku Subtema 2 Pemanfaatan Kekayaan Alam di Indonesia dengan materi Pelaksanaan Hak dan Kewajiban terhadap Sumber Energi dan Sumber Daya Alam. Instrumen penilaian sikap disiplin dikatakan sangat layak digunakan untuk menilai sikap disiplin siswa karena memperoleh hasil persentase sebesar 85,7\% dari ahli penilaian sikap yang masuk dalam kategori sangat tinggi dengan simpulan layak untuk digunakan. Hasil validasi ahli desain pembelajaran mendapatkan persentase sebesar 91,8\% yang termasuk dalam kategori sangat tinggi dengan simpulan layak untuk digunakan. Hasil validasi ahli bahasa mendapatkan hasil persentase sebesar 91,3\% yang tergolong kategori sangat tinggi dengan simpulan layak untuk digunakan. Berdasarkan hasil dari kategori tersebut maka produk instrumen penilaian sikap disiplin menggunakan skala likert dalam pembelajaran tematik kelas IV SD sangat layak untuk digunakan.

\section{DAFTAR PUSTAKA}

Djamarah, S. B. (2013). Strategi Belajar Mengajar. PT. Rineka Cipta.

Efendi, R. (2020). Manajemen Kelas di Sekolah Dasar. CV Penerbit Qiara Media.

Kartinah, K. (2018). Pengembangan Instrumen Pengukuran Disiplin untuk Siswa Sekolah Menengah Pertama. Wiyata Dharma: Jurnal Penelitian Dan Evaluasi Pendidikan, 6(2), 102-108. https://doi.org/10.30738/wd.v6i2.3387

Kemendikbud. (2016). Permendikbud Nomor 22 Tabun 2016 tentang Standar Proses Pendidikan Dasar dan Menengah. Kementerian Pendidikan dan Kebudayaan RI.

Kemendikbud. (2016). Permendikbud Nomor 24 Tabun 2016 tentang Kompetensi Inti dan Kompetensi Dasar. Kementerian Pendidikan dan Kebudayaan RI.

Kunandar. (2014). Penilaian Autentik (Penilaian Hasil Belajar Peserta Didik Berdasarkan Kurikulum 2013). Raja Grafindo Persada.

Mawardi. (2014). Model Desain Pembelajaran Konsep Dasar PKn Berbasis Belajar Mandiri menggunakan Moodle. Widya Sari Press. 
Mawardi, M. (2019). Rambu-rambu Penyusunan Skala Sikap Model Likert untuk Mengukur Sikap Siswa. Scholaria: Jurnal Pendidikan Dan Kebudayaan, 9(3), 292304. https://doi.org/10.24246/j.js.2019.v9.i3.p292-304

Prastowo, A. (2015). Menyusun Rencana Pelaksanaan Pembelajaran (RPP) tematik Terpadu. Penerbit Kencana.

Pratiwi, U., \& Fasha, E. F. (2015). Pengembangan Instrumen Penilaian Hots Berbasis Kurikulum 2013 Terhadap Sikap Disiplin. Jurnal Penelitian Dan Pembelajaran IPA, 1(1), 123-142. https://doi.org/10.30870/ippi.v1i1.330

Purnanto, A. W., \& Mustadi, A. (2018). Analisis Kelayakan Bahasa Dalam Buku Teks Tema 1 Kelas I Sekolah Dasar Kurikulum 2013. Profesi Pendidikan Dasar, 3(2), 102-111. https://doi.org/10.23917/ppd.v3i2.2773

Sani, R. (2016). Penilaian Autentik. PT Bumi Aksara.

Sugiyono. (2016). Metode Penelitian \& Pengembangan Research and Development. Penerbit Alfabeta Cv.

Sukmadinata. (2017). Metode Penelitian Pendidikan. PT Remaja Rosdakarya.

Wardani, N. (2012). Asesmen Pembelajaran SD. Widya Sari Press.

Wicaksono, T. P., Muhardjito, \& Harsiati, T. (2016). Pengembangan Penilaian Sikap dengan Teknik Observasi, Self Assessment, dan Peer Assessment pada Pembelajaran Tematik Kelas V SDN Arjowinangun 02 Malang. Jurnal Pendidikan: Teori, Penelitian, Dan Pengembangan, 1(1), 45-51. http://journal.um.ac.id/index.php/jptpp/article/view/5214 